\title{
НОВЫЕ РАДИАЦИОННО-ИНДУЦИРОВАННЫЕ БАКТЕРИЦИДНЫЕ ПЛЕНКИ НА ОСНОВЕ КАРБОКСИМЕТИЛХИТИНА И НАНОЧАСТИЦ СЕРЕБРА
}

\begin{abstract}
Л.Н. Широкова, В.А. Александрова
Лаборатория «Химии полиэлектролитов и медико-биологических полимеров» (№ 25), Федеральное государственное бюджетное учреждение науки Ордена Трудового Красного Знамени Институт нефтехимического синтеза им. А.В.Топчиева Российской академии наук (ИНХС РАН), 119991, ГСП-1, Россия, Москва, Ленинский проспект, 29.
\end{abstract}

DOI: 10.19163/MedChemRussia2021-2021-531

E-mail:shirokova@ips.ac.ru

Водорастворимое производное хитина 6-О-карбоксиметилхитин (КМX) является нетоксичным, биосовместимым, биодеградируемым и пленкообразующим полимером, что служит основанием для выбора этого полисахарида в качестве матрицы для синтеза наночастиц серебра.

В настоящей работе были изучены три степени заполнения макромолекул KMX в солевой форме (KMX-Na) на размер и форму наночастиц серебра, образующихся при радиационно-химическом восстановлении ионов $\mathrm{Ag}+$ (поглощенная доза 10кГр). Показано, что исходная концентрация ионов $\mathrm{Ag}+$ оказывает существенное влияние на процесс формирования наночастиц серебра. Учитывая это, в работе были исследованы три степени заполнения макромолекул $\mathrm{KMX-Na}-0.2,0.4$ и 0.6 от максимально возможного, согласно кривой сорбции [1]. Электронные спектры наносистем, полученных с использованием в качестве исходной матрицы KMX-Na, подтверждают, что радиационно-химическое восстановление ионов $\mathrm{Ag}+$ в наночастицы серебра происходит эффективно, при этом достигается оптическая плотность 2.3-2.4 (при $\lambda \max 420$ нм) для KMX-Na.

Анализ данных ПЭМ этих систем позволяет заключить, что для матрицы KMX-Na (pH 8.5) при степенях заполнения 0.2 и 0.4 образуются наночастицы серебра размером 1-5 нм сферической формы. Из полученного коллоидного раствора наночастиц серебра формовали пленочные нанокомпозиты по сухому способу на подложке из оргстекла. В экспериментах in vitro установлено, что как коллоидные растворы наночастиц серебра, так и пленочные наноматериалы проявляли бактерицидную активность по отношению к штаммам и грамположительных S. aureus, и грамотрицательных Salm. tythi бактерий [2].

\section{Литература}

[1] Aleksandrova V.A., Shirokova L.N. Polymer Science B. 2018. V. 60. № 6. P. 727.

[2] В.А. Александрова, Л.Н. Широкова Коллоидный раствор наночастиц серебра, металл-полимерный нанокомпозитный пленочный материал, способы их получения, бактерицидный состав на основе коллоидного раствора и бактерицидная пленка из металл-полимерного материала / Патент России № 2474471. 2013. Бюл. № 4. 